\title{
SERUM ZINC STATUS IN PATIENTS WITH HAEMOGLOBIN-E $\beta$ THALASSEMIA
}

\author{
Morshed AKMA ${ }^{1}$, Islam $\mathrm{S}^{2}$, Chowdhury $\mathrm{TR}^{3}$, Islam $\mathrm{A}^{4}$, Islam $\mathrm{A}^{5}$, Begum $\mathrm{H}^{6}$, Haq $\mathrm{SA}^{7}$, Dey $\mathrm{P}^{8}$
}

\begin{abstract}
:
Background: $H b-E$ â thalassemia is a major congenital hematological disease of Bangladesh. The patients have poor growth and delayed maturation mainly due to iron overload but zinc deficiency also has been suggested as a contributing factor. The aim of this study was to investigate and compare the serum zinc of $\mathrm{HbE}-\hat{a}$ thalassemia patients and normal children.
\end{abstract}

Methods: This cross sectional study was done in the Department of Paediatric Haematology and Oncology of Bangabandhu Sheikh Mujib Medical University (BSMMU), Dhaka, from July 2009 to May 2010. A total of 31children with Hb-E â thalassemia were enrolled for this study and besides, matched 30 healthy children were taken as control. After initial assessment the cases were thoroughly examined by the investigators and history of transfusion, transfusion interval were recorded. Venous blood samples $(3 \mathrm{~mL})$ were drawn from patients and normal control children then centrifuged and stored at $-20^{\circ} \mathrm{C}$ until analyzed. Serum level of zinc was measured by using Flame Atomic Absorption Spectrophotometry.

Results: Mean serum zinc level in thalassemic group and control group were $97.4 \mu \mathrm{g} / \mathrm{dl}$ ( $\mathrm{SD}$ $18.4)$ and $99.6 \mu \mathrm{g} / \mathrm{dl}(\mathrm{SD}-18.7)$ respectively. There is no significant difference between two groups $(p=0.47)$.

Conclusion: It may be concluded from this study that serum zinc level did not significantly change in children with $H b-E$ a thalassemia .

Key words: Children, Hb-E â thalassemia, zinc.

J Dhaka Med Coll. 2013; 22(2) : 115-119.

\section{Introduction:}

Thalassemia is the commonest hereditary hematological disorder ${ }^{1}$. Thalassemias are prevalent in populations that evolved in humid climates where malaria was endemic. It affects all races, as thalassemias protected these people from malaria due to the blood cells easy degradation. Thalassemias are particularly associated with people of Mediterranean origin, Arabs, and Asians ${ }^{1}$. The Maldives has the highest incidence of thalassemia in the world with a carrier rate of $18 \%$ of the population. The estimated prevalence is $16 \%$ in Cyprus, $1 \%$ in Thailand and 3-8\% in populations from Bangladesh, China, India, Malaysia and
Pakistan $^{2}$. There are also prevalences in descendants of people from Latin America and Mediterranean countries (e.g. Greece, Italy, Portugal, Spain, and others). A very low prevalence has been reported from people in Northern Europe $(0.1 \%)$ and Africa $(0.9 \%)^{2}$.

The World Health Organization (WHO) estimates that in Thailand at least 100,000 new cases of $\mathrm{Hb}-\mathrm{E}$ â thalassemia are expected in the next few decades. Among all thalassemia syndrome Hb-E-â thalassemia is the most common in our country and in south east Asia $^{3,4}$. Hemoglobin E Syndrome carrier frequency in Bangladesh is $6 \% 5,6$.

1. Dr. AKM Amirul Morshed, Associate Professor, Department of Paediatric Haematology and Oncology, Dhaka Medical College \& Hospital, Dhaka.

2. Dr. Shahnoor Islam, Assistant Professor, Department of Paediatric Surgery, Dhaka Medical College \& Hospital, Dhaka.

3. Tasrina Rabeya Chowdhury, Senior Scientific Officer, Chemistry Division, Atomic Energy Centre, Ramna, Dhaka.

4. Prof. Afiqul Islam, Chairman, Department of Paediatric Haematology and Oncology, Bangabandhu Sheikh Mujib Medical University (BSMMU), Dhaka.

5. Dr. Ariful Islam, Assistant Professor, Department of Paediatrics, Dhaka Medical College \& Hospital, Dhaka.

6. Dr. Helena Begum, Assistant Professor, Department of Paediatric Haematology and Oncology, Bangabandhu Sheikh Mujib Medical University (BSMMU), Dhaka.

7. Dr. Sheikh Azimul Haq, Assistant Professor, Department of Paediatrics, Dhaka Medical College \& Hospital, Dhaka. 8. Dr. Pritam Dey, Research Fellow, ICDDRB, Dhaka

Correspondence : Dr. AKM Amirul Morshed, Associate Professor, Department of Paediatric Haematology and Oncology, Dhaka Medical College and Hospital, Dhaka. Email: amirul_morshed63@yahoo.com 
Zinc is an essential trace element that is required for normal intestinal mucosal integrity, skeletal growth, sodium and water transport and immune function. Clinical zinc deficiency is prevalent in Bangladesh, particularly among malnourished children and who are suffering from chronic diseases. Zinc is an essential trace metal for the normal function of many enzymes involved in cell division and DNA protein synthesis in mankind . Zinc deficiency is associated with several clinical manifestations, such as growth retardation, delayed wound healing skin changes, hypogonadism, glucose intolerance, anemia and reduced leucocyte function. Patients with thalassemia major not receiving regular chelation treatment or blood transfusion also have serum zinc values below normal and they have increased urinary zinc excretion ${ }^{7}$. A study in India had shown that zinc deficiency aggravate anemia ${ }^{8}$. It has been recognized for several decades that children with $\mathrm{Hb}-\mathrm{E}$ a thalassemia have poor growth and delayed puberty $9,10,11$. Iron overload is the main reason for these disorders, but zinc deficiency has been suggested as a contributing factor in these patients. Trace minerals, especially zinc, are very important for human growth, puberty and immune system ${ }^{12}$. On the other hand, iron chelation therapy with desferrioxamine, which is necessary for major thalassemic patients, increases urinary excretion of zinc ${ }^{13}$. Zinc status in patients with thalassemia has been under debate ${ }^{14}$. The studies of Shamshirsaz, Bekheiia and Arcasoy showed that serum zinc level is less than normal in $80-100 \%$ of the patients ${ }^{15,16,17}$. However, in other studies serum zinc level was not statistically different in thalassemic subjects compared with a control group and even Donma found higher values for hair zinc in patients with thalassemia ${ }^{18}$. As there have been some reports indicating positive effects of oral zinc supplementation on height velocity in children with definite zinc deficiency ${ }^{12}$, some thalassemic patients in our country receive zinc supplement, even though its necessity and efficacy are vague. Several studies have shown the status of zinc in Beta thalassemia major but no study specifically done on $\mathrm{Hb}-\mathrm{E}$ â thalassemic patients. Considering this and different zinc status in different studies in thalassemic patients, the study was taken to investigate and compare serum zinc level in $\mathrm{Hb}-\mathrm{E}$ â thalassemic patients and normal individuals.

\section{Methods:}

A cross sectional study was conducted at Department of Pediatric Hematology and Oncology, Bangabandhu Sheikh Mujib Medical University (BSMMU), Dhaka and Thalassemia Centre of Dhaka Shishu Hospital, Dhaka, from July 2009 to May 2010. Inclusion criteria were diagnosed cases of $\mathrm{Hb}-\mathrm{E}$ â thalassemia patients of 2-12 years of age attending BSMMU Hospital and Thalassemia Centre of Dhaka Shishu Hospital, Dhaka. Informed consent had been taken from the parents. Patients who have any associated medical conditions (e.g.Protein Energy Malnutrition (PEM), congenital cardiac disease, bronchial asthma, neurological disorders and haemoglobinopathies etc), children taking any dietary supplement containing zinc during the last month and acute febrile infected children based on physical examination at the time of blood sampling were excluded because zinc level reduce in febrile illness ${ }^{19}$. In this study, 31 patients with $\mathrm{Hb}-\mathrm{E}$ â thalassemia, who were on regular blood transfusion in 2 (two) thalassemia centres in Dhaka, entered into this study from July 2009 to May 2010. Diagnosis of $\mathrm{Hb}-\mathrm{E}$ â thalassemia was based on peripheral blood smear evaluation and hemoglobin electrophoresis of the patients. Patients were excluded from this study if they had any underlying medical condition other than thalassemia, or any dietary supplement containing zinc during the last month as it may interfere with the result of the study. Patients who were febrile (oral temperature $>38^{\circ} \mathrm{C}$ ) or was acute infection based on physical examination at the time of blood sampling were also excluded because zinc level reduce in febrile illness ${ }^{19}$. Consent was obtained from their parents. Anthropometric data, time of diagnosis, time interval between blood transfusions, history of splenectomy and patient medications collected by researcher himself. Blood samples $(3 \mathrm{~mL})$ were drawn from 
patients and then centrifuged and stored at $20^{\circ} \mathrm{C}$ until analyzed. Serum level of zinc was measured using flame atomic absorption spectrometry (Atomic absorption spectrophotometer Perkins Elmer model no 3110, Germany) in Analytical Chemistry laboratory of Atomic Energy Centre, Dhaka. Serum samples were diluted $(1: 1)$ with deionized water. The viscosity of the diluted serum samples was then matched effectively with the working standard. The working standard solution was prepared by diluting a stock solution containing $1000 \mathrm{mg} / \mathrm{L}$ of single element AAS grade standard with ultra pure water and 5\% glycerin. A Varian (Varian, DuoAA240FS and AA280Z) atomic absorption spectrometer (AAS) equipped with fully integrated atomizers (viz. a burner system for flame atomization), was used for doing analysis. Serum zinc level less than 60ig/dL was regarded as low. Thirty age- and sex-matched healthy children from out patient department of BSMMU who have the same socioeconomic status were selected and their serum zinc level was analyzed.

Data was taken in well validated questionnaire which was pre-tested by few samples in OPD of Paediatric Haematology and Oncology department of BSMMU. Data was processed by computer software SPSS Version 16.0 and results were analyzed by $\chi^{2}$ test and Anova test. Due to the economical constraints and time limit large sample could not taken and other investigations like feritin level and relationship between serum ferritin and zinc could not established. This protocol was approved by the ethical committee of BSMMU, Dhaka.

\section{Results:}

The study included 31 children suffering from $\mathrm{Hb}$ E- $\beta$ thalassemia and 30 children are healthy age and sex matched controls who are not suffering from thalassemia. Mean age of this study was 79.8 months with standard deviation 38.3 months range from $24-144$ months in patients with $\mathrm{HbE}$ - â thalassemia and those in control group mean age was 74.4 months with SD-36.3, maximum 144 and minimum 24 months. Total $26(42 \%)$ children were male while $35(58 \%)$ children were female in this study. In $\mathrm{Hb}$ E- â thalassemia group 13(42\%) cases were male while $18(58 \%)$ cases were female but in control group it was $13(43 \%)$ and $17(57 \%)$ respectively. Four children $(7 \%)$ had come from a family with consanguinity of marriage while $57(93 \%)$ had come from family of non-consanguinity of marriage. In $3(10 \%)$ children of $\mathrm{Hb}$ E-â thalassemia group were from family of consanguinity while it were only in $1(3 \%)$ in the control group. Twenty two $(71 \%)$ cases of $\mathrm{Hb} \mathrm{E}-\beta$ thalassemia had palpable liver and in $09(29 \%)$ cases liver was not palpable. Mean length of palpable liver was $2.9 \mathrm{~cm}$ ranging from $1 \mathrm{~cm}$ to $8 \mathrm{~cm}$. Incase of spleen, there were $29(93 \%)$ cases came with palpable spleen with mean length of $6.8 \mathrm{~cm}$ ranging from $1 \mathrm{~cm}$ to $15 \mathrm{~cm}$. Splenectomy was done in one case of $\mathrm{Hb} \mathrm{E}-\beta$ thalassemia patient.

Haematological parameters of both groups were extremely variable. In $\mathrm{Hb}-\mathrm{E}$ â thalassemia group mean haemoglobin level was $6.1 \mathrm{gm} / \mathrm{dl}$

\section{Table-I}

Haematological parametrs of the cases

\begin{tabular}{lccccccccc}
\hline Haematological & \multicolumn{3}{c}{ Hb-E $\beta$ thalassemia group } & \multicolumn{3}{c}{ Control group } & \multicolumn{3}{c}{ p value } \\
parametrs & Mean & SD & Min. & Max. & Mean & SD & Min. & Max. & \\
\hline Haemoglobin $(\mathrm{gm} / \mathrm{dl})$ & 6.1 & 0.7 & 4.5 & 7.2 & 11.6 & 1.6 & 8.9 & 14.5 & 0.001 \\
$\mathrm{MCV}(\mathrm{fl})$ & 62 & 4.4 & 54 & 70 & 82.7 & 6.2 & 71 & 92 & 0.001 \\
$\mathrm{MCH}(\mathrm{pgm})$ & 20.2 & 1.9 & 17 & 25 & 26.6 & 2.7 & 20 & 30 & 0.001 \\
$\mathrm{MCHC}(\mathrm{gm} / \mathrm{dl})$ & 26.5 & 2.3 & 18 & 31 & 30 & 2.5 & 25 & 34 & 0.001 \\
\hline
\end{tabular}


(SD-0.7). In control group, it was 11.6 (SD-1.6). There were significant different between two comparable groups $(p=0.001)$. Mean Corpuscular Volume (MCV) of RBC of Hb-E $\beta$ thalassemia group was significantly low from control group $(p=0.001)$. Mean MCV in first group was $62 \mathrm{fl}$ (SD-4.4), while that of control group was $82.7 \mathrm{fl}$ (SD-6.2). Mean corpuscular haemoglobin $(\mathrm{MCH})$ of $\mathrm{Hb}-\mathrm{E} \beta$ thalassemia group was significantly lower than that of control group $(p=0.001)$. Mean $\mathrm{MCH}$ of thalassemic group was $20.2 \mathrm{pgm}$, while in control group it was 26.6 pgm. Mean corpuscular hemoglobin concentration (MCHC) also lower in Hb-E $\beta$ thalassemia group than control group. Mean $\mathrm{MCHC}$ in thalassemic group was $26.5 \mathrm{gm} / \mathrm{dl}$, but mean MCHC in control group was $30 \mathrm{gm} /$ $\mathrm{dl}(\mathrm{p}=0.001)$ (table-I).

Table-II

Serum zinc level of the children

\begin{tabular}{|c|c|c|c|c|c|}
\hline \multirow[t]{2}{*}{ Group } & \multicolumn{4}{|c|}{ Serum zinc level $(\mu \mathrm{g} / \mathrm{dl})$} & $\mathrm{P}$ \\
\hline & Mean & $\mathrm{SD}$ & Min. & Max. & value \\
\hline$\overline{\mathrm{Hb}-\mathrm{E} \beta}$ & 97.6 & 18.4 & 69 & 146 & \\
\hline Thalassemia group & & & & & 0.47 \\
\hline Control group & 99.6 & 18.7 & 71 & 145 & \\
\hline
\end{tabular}

Mean serum zinc level in $\mathrm{Hb}-\mathrm{E} \beta$ thalassemia group was $97.6 \mu \mathrm{g} / \mathrm{dl}$ and in control group it was $99.6 \mu \mathrm{g} / \mathrm{d}$ l. There was no significant difference of serum zinc level in $\mathrm{Hb}-\mathrm{E} \beta$ thalassemia group and control group $(p=0.47)$ (table-II). There is no relation with serum zinc level and gender of the children. Mean zinc level in male was 99.6 (SD-19.7) and female it was 96.3 (SD-17.0). $(p=0.9)$. There is no relation in serum zinc level and different age group of the children $(p=0.69)$. (table-III \& IV)

Table-III

Serum zinc level in relation to the gender distribution

\begin{tabular}{lccccc}
\hline Gender & \multicolumn{4}{c}{ Serum zinc level $(\mu g / d 1)$} & $P$ \\
& Mean & SD & Min. & Max. & value \\
\hline Male & 99.6 & 19.7 & 71 & 146 & 0.9 \\
Female & 96.3 & 17.0 & 69 & 140 & \\
\hline
\end{tabular}

Table-IV

Serum zinc level in relation to distribution of age

\begin{tabular}{|c|c|c|c|c|c|}
\hline \multirow[t]{2}{*}{ Age stratum(n=61) } & \multicolumn{4}{|c|}{ Serum zinc level $(\mu \mathrm{g} / \mathrm{dl})$} & \multirow{2}{*}{$\begin{array}{c}\mathrm{P} \\
\text { value } \\
\end{array}$} \\
\hline & Mean & $\mathrm{SD}$ & Min. & Max. & \\
\hline$<24$ months $(\mathrm{n}=5)$ & 94.4 & 12.6 & 78 & 112 & 0.69 \\
\hline 24-60 months $(n=25)$ & 101.1 & 21.1 & 75 & 146 & \\
\hline $61-90$ months $(n=10)$ & 93.9 & 19.1 & 71 & 130 & \\
\hline >90months $(\mathrm{n}=21)$ & 96.8 & 15.8 & 69 & 120 & \\
\hline
\end{tabular}

\section{Discussion:}

In this study, 31 children were patients and 30 were taken as control. Age and sex matched population who had no thalassemia or no major illness was taken as control population. The participating children were predominantly urban residents (around 60\%). In thalassemia patients, the male: female ratio was roughly $2: 3$, which was not consistent with the study conducted in Bangladesh by Rahman and $\mathrm{Jamal}^{3}$, where the same ratio was roughly $1: 1$. In our study, mean age in the study group was approximately 80 months with a standard deviation of 38 months. The youngest and the oldest children were of 24 and 144 months respectively. These findings are almost consistent with the findings of Rahman and $\mathrm{Jamal}^{3}$. However, Mehdizadeh et al. ${ }^{12}$ in a similar study reported a higher mean age in their study (164 \pm 69.6 months). The difference between $\mathrm{Hb}-\mathrm{E}$ â thalassemia and control groups in terms of consanguinity of marriage was negligible $(10 \%$ vs. $3 \%)$ and is staggeringly low compared with Shiraj's study conducted in Iranian population where $>40 \%$ of patients of â thalassemia major had consanguinity of marriage $^{20}$. In the absence of local data about consanguinity of marriage we cannot make any conclusion about it. In the present study 93\% and $71 \%$ of the patients with $\mathrm{Hb}-\mathrm{E}$ â thalassemia exhibited palpable liver and spleen. One patient was found with previous splenectomy. But in a local study nearly all patients had enlarged liver and spleen and 3 patients presented with previous splenectomy $(n=126)^{3}$. Our result differed from this study in both enlargements of liver and spleen which might be due to frequent blood transfusion in our cases.

The findings of the present study showed that the mean serum zinc level of $\mathrm{Hb}-\mathrm{E}$ â thalassemia group was almost identical with 
that of the control group $97.6 \pm 18.4 \mu \mathrm{g} / \mathrm{dl}$ vs. $99.6 \pm 18.7 \mu \mathrm{g} / \mathrm{dl}(\mathrm{p}=0.47)$. Our study did not coincide with previous Iranian study where mean serum zinc level in beta thalassemia major children was significantly higher $(108.16 \pm 17.2 \mu \mathrm{g} / \mathrm{dl})$ than that in normal children $(93.56 \pm 13.6 \mu \mathrm{g} / \mathrm{dl})^{12}$. Sharply contrasting with these findings in Egyptian study showed that there was significantly lower level of zinc in thalassemic population than that in the normal children where serum zinc level was $88.3 \pm 17.7 \mu \mathrm{g} / \mathrm{dl}$ vs. $113.5 \pm 15.4 \mu \mathrm{g} / \mathrm{dl}$ respectively $^{21}$. Al-Refaie et al. ${ }^{7}$ reported that zinc level in thalassemic children was $88.4 \pm 11.5 \mu \mathrm{g} / \mathrm{dl}$, which was much lower than that of Iranian study ${ }^{12}$. Although different investigators showed different results (some with lower and some with higher serum zinc level in Hb-E â thalassemic children compared to the control group) our study did not show any significant difference between $\mathrm{Hb}-\mathrm{E}$ â thalassemic and control group children in terms of serum level of zinc.

\section{Conclusion:}

It can be concluded that there was no significant difference between $\mathrm{Hb}-\mathrm{E}$ â thalassemia children and normal control children in terms serum zinc level. Moreover, mean serum zinc level is within normal range in children with $\mathrm{Hb}-\mathrm{E}$ â thalassemia and normal control children. Hence, supplementation of zinc in children with $\mathrm{Hb}-\mathrm{E}$ â thalassemia is not essential.

\section{References:}

1. Olivieri NF, Wetherall DJ. Thalassemia. In:Lilleyman JS, Hann IM, Blanchette VS. eds. Pediatric Hematology. $2^{\text {nd }}$ ed. London: Churchill Livingstone; 1999: 307-27

2. Uthman ED. Hemoglobinopathies and Thalassemias Available on: http://web2. airmail. net/ uthman/index.html. [Accessed on 05/31/2010].

3. Rahman SA, Jamal CY. Congenital hemolytic anemia in Bangladesh: types and clinical manifestations. Indian Pediatr 2002; 39: 574-7.

4. Vichinsky E. Hemoglobin E sindromes. Hematology. Am Soc Hematol Educ Program 2007:79-83

5. Weatherall DJ, Clegg JB. Inherited haemoglobin disorders: an increasing global health problem. Bull World Health Organ 2001; 79: 704-12.

6. Gibbons R, Higgs DR, Olivieri NF, Wood WG. The $ß$ and $\beta$ thalassaemias in association with structural haemoglobin variants. In: Weatherall DJ, Clegg JB. eds. The Thalassaemia Syndromes. $4^{\text {th }}$ ed. Oxford: Blackwell Science; 2001: 393-449.
7. Al-Refaie FN, Wonke B, Wickens DG, Aydinok Y, Fielding A , Hoffbrand AV. Zinc concentration in patients with iron overload receiving oral iron chelator 1,2- dimethyle -3-hydroxypyrid-4-one or desferoxamine. J Clin Pathol 1994; 47: 657-60.

8. Mahajan SK. Zinc in kidney disease. J Am Coll Nutr 1989; 8: 296-304.

9. Raiola G, Galati MC, De Sanctis V, Nicoletti CM, Pintor C, De Simone M, et al. Growth and puberty in thalassemia major. J Pediatr Endocrinol Metab 2003; 16: 259-66.

10. Saka N, Sukur M, Bundak R, Anak S, Neyzi O, Gedikoðlu G. Growth and puberty in thalassaemia major. J Pediatr Endocrinol Metab 1995; 8: 181-6.

11. Sanctis De V. Growth and puberty and it's management in thalassaemia. Horm Res. 2002; 58: $72-9$.

12. Mehdizadeh M, Zamani G, Tabatabaee S. Zinc Status in Patients with Major B-Thalassemia. Pediatr Hematol Oncol 2008; 25: 49-54

13. Uysal Z, Akar N, Kemahli S, Dincer N , Arcasoy A. Desferrioxamine and urinary zinc excretion in beta-thalassemia major. Pediatr Hematol Oncol 1993; 10: 257-60.

14. Fuchs GJ, Tienboon P, Linpisarn S, Nimsakul S, Leelapat $\mathrm{P}$, Tovanabutra S, et al. Nutritional factors and thalassemia major. Arch Dis Child 1996 ;74: 224-7.

15. Shamshirsaz A, Bekheirnia MR, Kamgar M. Metabolic and endocrinologic complications in beta-thalassemia major: a multicenter study in Tehran. BMC Endocrine Disorders 2003; 3: 4.

16. Bekheiia MR, Shahirsaz AA, Kamgar M, Bouzari N, Erfanzadeh G, Pourzahedgilani N etal. Serum zinc and its relation to bone mineral density in beta-thalassemic adolescents. Biol Trace Elem Res 1993; 97: 215-24.

17. Arcasoy A, Canata D, Sinav B, Kutlay L, Oguz N, Sen M. Serum zinc levels and zinc binding capacity in thalassemia. J Trace Elem Med Biol 2001; 15: 85-7.

18. Donma O, Gunbey S, Tas MA, Donma MM. Zinc, copper, and magnesium concentrations in hair of children from southeastern Turkey. Biol Trace Elem Res 1990; 24: 39-47.

19. Mollah MAH, Raksit SC, Anwar KS, Arslan MI, Ahmed S, Shaha N, et al. Zinc concentration in serum and CSF simultaneously decrease in children with febrile seizure; findings from a prospective study in Bangladesh. Acta Paediatrica 2008; 97: 1707-11.

20. Asadi-Pooya AA, Doroudch M. Thalassemia major and consanguinity in Shiraz city, Iran. Turk J Haematol 1993; 21: 127-30.

21. Fikry SI, Saleh SA, Sarkis NN, Mangoud H. Study of serum zinc in relation to nutritional status among thalassemia patients in Damanhour Medical National Institute. J Egypt Public Health Assoc 2003; 78: 73-93. 